\title{
Dietary fat intake and risk of epithelial ovarian cancer by tumour histology
}

\author{
M A Merritt ${ }^{\star}, 1,2,3$, D W Cramer ${ }^{1,2}$, S A Missmer ${ }^{1,4,5}$, A F Vitonis ${ }^{2}$, L J Titus ${ }^{6}$ and K L Terry ${ }^{1,2}$
}

${ }^{1}$ Department of Epidemiology, Harvard School of Public Health, 677 Huntington Avenue, Boston, MA 02115, USA; ${ }^{2}$ Obstetrics and Gynecology Epidemiology Center, Department of Obstetrics and Gynecology, Brigham and Women's Hospital and Harvard Medical School, 221 Longwood Avenue, Boston, MA 02115, USA; ${ }^{3}$ Department of Epidemiology and Biostatistics, School of Public Health, Imperial College London, London W2 1PG, UK; ${ }^{4}$ Division of Reproductive Medicine, Department of Obstetrics, Gynecology and Reproductive Biology, Brigham and Women's Hospital and Harvard Medical School, 221 Longwood Avenue, Boston, MA 02115, USA; ${ }^{5}$ Channing Division of Network Medicine, Department of Medicine, Brigham and Women's Hospital and Harvard Medical School, 181 Longwood Avenue, Boston, MA 02115, USA and ' Department of Community and Family Medicine, Dartmouth Medical School, Geisel School of Medicine at Dartmouth, One Medical Center Drive, HB 7926, Lebanon, NH 03756, USA

Background: Studies of fat intake and epithelial ovarian cancer (EOC) risk have reported inconsistent findings, hence we hypothesised that associations may vary by histologic subtype.

Methods: We evaluated fat intake in a New England case-control study including 1872 cases and 1978 population-based controls (1992-2008). Epithelial ovarian cancer risk factors and diet were assessed using a food frequency questionnaire at enrolment. Logistic regression was used to estimate associations between fat intake and EOC risk and polytomous logistic regression was used to test whether associations varied by histologic subtype.

Results: We observed a decreased risk of EOC when comparing the highest vs lowest quartiles of intake of omega-3 (odds ratio $(\mathrm{OR})=0.79,95 \%$ confidence interval $(\mathrm{Cl}) 0.66-0.96, P$-trend $=0.01)$ and omega-6 $(\mathrm{OR}=0.77,95 \% \mathrm{Cl} 0.64-0.94, P$-trend $=0.02)$ and an increased risk with high consumption of trans fat $(\mathrm{OR}=1.30,95 \% \mathrm{Cl} 1.08-1.57, P$-trend $=0.002)$. There was no significant heterogeneity by tumour histologic subtype; however, we observed a strong decreased risk for endometrioid invasive tumours with high intake of omega-3 (quartile (Q) 4 vs $\mathrm{Q} 1, \mathrm{OR}=0.58,95 \% \mathrm{Cl} 0.41-0.82, P$-trend $=0.003$ ).

Conclusions: These findings suggest that higher intake of omega-3 may be protective for EOC overall and endometrioid tumours in particular, whereas greater consumption of trans fat may increase risk of EOC overall.

Dietary factors could explain some of the observed differences in ovarian cancer incidence rates worldwide, which are higher in industrialised countries than in developing countries (Ferlay et al, 2010). Earlier ecologic studies reported strong positive correlations between dietary fat intake and ovarian cancer risk (Armstrong and Doll, 1975; Prentice and Sheppard, 1990); however, inconsistent findings have been reported regarding the association between fat intake and epithelial ovarian cancer (EOC) risk. The NIH-AARP cohort and a meta-analysis of eight observational studies
(Huncharek and Kupelnick, 2001; Blank et al, 2012) reported a positive association between total fat intake and EOC risk overall, whereas other studies (Byers et al, 1983; Salazar-Martinez et al, 2002; Pan et al, 2004; Genkinger et al, 2006; Chang et al, 2007; Gilsing et al, 2011) found no association. A recent pooled analysis that included data from 12 cohort studies showed no association between the consumption of different types (monounsaturated, polyunsaturated, trans) or sources of fat (animal and vegetable fats) and EOC risk (Genkinger et al, 2006). A weak positive association 
with saturated fat intake was reported in the pooled analysis (highest $v s$ lowest decile of intake (relative risk $(\mathrm{RR})=1.29,95 \%$ confidence interval (CI) 1.01-1.66). In the Women's Health Initiative Dietary Modification randomised controlled trial, a low fat and high fruit, vegetable and grain dietary pattern ( $v s$ usual diet) was associated with a reduced risk for EOC in postmenopausal women after $4-8$ years of follow-up $(\mathrm{RR}=0.60,95 \% \mathrm{CI} 0.38-0.96$; Prentice et al, 2007).

Together these studies suggest a possible role for fat intake in the aetiology of EOC; however, with the exception of the pooled analysis, previous studies were limited by small sample sizes that reduced the ability to assess differences in the risk associations among the histologic subtypes of EOC. In the pooled analysis, there was no significant difference in the risk estimates for different types and sources of fat intake between serous, endometrioid and mucinous subtypes (Genkinger et al, 2006); however, in this study omega-3/omega-6 were not evaluated separately in analyses by histologic subtype and borderline tumours were not included as cases.

As the adverse effects of total, trans and saturated fat intake contrasts with the beneficial effects of other fats (including the long chain omega-3 $(n-3)$ fatty acids, which may have antitumourigenic properties; Larsson et al, 2004), detailed analyses of the type and source of fat intake in relation to EOC risk according to the histologic subtype are needed. In this large population-based case-control study of ovarian cancer, we evaluated different sources and types of fat consumption in relation to risk of EOC overall and its major histologic subtypes.

\section{MATERIALS AND METHODS}

Study population. Details of the case and control enrolment in the New England Case-Control (NECC) study were previously described (Terry et al, 2005; Harris et al, 2011); in brief, cases and controls from the NECC study of ovarian cancer come from three enrolment phases (1992-1997, 1998-2002 and 2003-2008) corresponding to three funding periods. During the combined study phases, we identified 3957 women (1080 from 1992 to 1997, 1267 from 1998 to 2002 and 1610 from 2003 to 2008) residing in eastern Massachusetts (MA) or New Hampshire (NH), USA with a diagnosis of incident ovarian cancer from hospital tumour boards and state cancer registries. Of these, 3083 (78\%) of the cases met the study's eligibility criteria; in total, 874 were ineligible because they could not be contacted because they had died $(N=391)$, moved or had no telephone $(N=280)$, did not speak English $(N=66)$, had a non-ovarian primary tumour after review $(N=126)$ or lived outside the study area $(N=11)$. Physicians declined permission to contact 360 cases and 520 cases declined or were too ill to participate leaving 2203 ( $71 \%$ of eligible cases) that were enrolled. This analysis included 2076 epithelial tumours of ovarian, primary peritoneal and fallopian tube origin.

Tumour characteristics (histology and behaviour) were abstracted from pathology reports by a gynaecologic pathologist. We examined the associations with fat intake according to tumour behaviour (invasive, borderline) and in the four major histologic subtypes of EOC (invasive tumours only; serous, mucinous, endometrioid and clear cell). Other mixed epithelial tumours $(N=70)$, malignant Brenner tumours $(N=4)$, unspecified epithelial $(N=25)$ and undifferentiated tumours $(N=41)$ were classified as other/undifferentiated. Owing to their uncertain aetiology, carcinosarcomas (mixed mesodermal Mullerian tumours, $N=35$ ) were excluded from all analyses.

Controls enrolled between 1992 and 1997 were selected using random digit dialling supplemented with lists of residents for controls over age 60 years in MA. Controls enrolled between 1998 and 2008 were identified through town books in MA and drivers' license lists in NH. Between 1992 and 1997, 420 (72\%) and 102 (51\%) of the eligible controls identified through random digit dialling and town resident lists, respectively, agreed to participate. From 1998 to 2008, 4366 potential controls were identified of whom 2940 (67\%) were eligible; 1362 (46\%) declined to participate by phone or by mail via an 'opt-out' postcard and 1578 (54\%) were enrolled $(N=2100$ total). Controls were frequency matched to cases based on age and state of residence. Controls exhibited similarities in their age at enrolment, body mass index (BMI), duration of oral contraceptive (OC) use (among ever users) and total caloric intake across the three study phases (data not shown). Study participants were interviewed in-person at the time of enrolment about known and putative EOC risk factors that occurred at least one year before diagnosis (for cases) or enrolment (for controls). Institutional review boards at the Brigham and Women's Hospital and the Dartmouth Medical School approved the study and all participants provided written informed consent.

Diet assessment. Dietary intake that occurred at least 1 year before diagnosis or study enrolment was assessed at the time of enrolment using a semiquantitative food frequency questionnaire (FFQ) (Willett et al, 1985; Rimm et al, 1992). The validity of this FFQ to measure fat intake has been previously demonstrated in the Nurses' Health Study (Holmes et al, 2000) when higher total fat intake as measured by the FFQ was strongly associated with lower plasma fasting triglyceride levels and fatty acid intakes calculated from the FFQ were moderately correlated with fatty acid levels measured in subcutaneous adipose tissue aspirates (polyunsaturated fatty acid, Spearman correlation 0.40; trans fatty acid, Spearman correlation 0.40; Garland et al, 1998). In the current analyses, fat intake (including fats used in cooking or baking) was calculated by multiplying the frequency of intake of each food containing each type of fat by the nutrient content of specified portions determined from the food composition values available from the USDA food composition data (U.S. Department of Agriculture Agricultural Research Service, 2011). The top two dietary sources of each fat type over the entire study period were as follows: total fat - beef (8.9\%) and hard cheese (5.9\%); vegetable fat - mayonnaise (8.6\%) and nuts (8.1\%); animal fat - beef $(16.8 \%)$ and hard cheese (11.0\%); dairy fat - hard cheese (26.2\%) and skim/ low fat milk (11.7\%); trans fat - beef (14.6\%) and crackers (10.6\%); saturated fat - hard cheese (10.7\%) and beef (10.2\%); cholesterol eggs $(20.1 \%)$ and chicken without skin (14.3\%); monounsaturated fat - beef (10.4\%) and nuts (5.0\%); polyunsaturated fat mayonnaise (11.9\%) and nuts (6.9\%); long chain $n-3$ - dark fish $(40.6 \%$, e.g., mackerel, salmon, sardines, bluefish and swordfish) and other fish (18.5\%); omega-6 $(n-6)$ - mayonnaise $(11.2 \%)$ and chicken without skin (7.5\%). The 140-item questionnaire included questions about the dosage and duration of supplemental vitamin usage. In analyses of long chain $n-3$ (eicosapentaenoic acid (EPA), docosapentaenoic acid (DPA) and docosahexaenoic acid (DHA)) and total $n-6$, intakes from food and food plus supplements were evaluated separately.

Statistical analysis. Participants were excluded from the analysis if they did not complete a FFQ $(N=76$ cases and $N=60$ controls $)$ or if they had an implausibly low or high caloric intake $(<500$ or $>3500 \mathrm{kcal} \mathrm{day}^{-1} ; N=93$ cases and $N=62$ controls). Participants included in this analysis had $<75$ blank food items $(N=19$ participants had between 15 and 74 blank food items). Energyadjusted nutrient intakes were calculated using the residuals from the regression of the log-transformed nutrient intake based on a total caloric intake of $1600 \mathrm{kcal} \mathrm{day}^{-1}$ (Willett and Stampfer, 1986). In selected sensitivity analyses, we also used the nutrient density method (Willett and Stampfer, 1998) and divided the energy intake from each fat by the total caloric intake while including total caloric intake in the model. Quartile cutpoints for each nutrient 
were calculated based on the distribution of intake among controls. Unconditional logistic regression was used to estimate the odds ratios (OR) and 95\% CIs for fat intake in relation to risk of EOC. Factors that were evaluated as potential confounders included wellestablished or putative risk factors for EOC and/or factors that may be associated with fat intake such as BMI. Multivariable analyses were adjusted for age (continuous), number of pregnancies $(0,1,2$, $3,>3$ ), OC use (none, 3 months $-<1$ year, $1-5$ years, $>5$ years), tubal ligation, family history of ovarian cancer in a first-degree relative, study centre (MA, NH) and study phase (1992-1997, 1998-2003, 2003-2008); the latter two factors account for the frequency matching on age that was used for the selection of controls within each study centre and phase and adjustment for study phase may also account for possible secular trends in diet. Additional potential confounders were evaluated (total caloric intake, BMI, history of endometriosis, menopausal status, postmenopausal hormone use, age at menarche, smoking status, race and education level) but were not included in the final models because they did not substantially alter the risk estimates by $>10 \%$ (Greenland, 1989). Tests for linear trend were performed using the Wald test with a trend variable assigned the median value of each quartile. We assessed effect modification by age $(<50, \geqslant 50$ years, 1 year before diagnosis or study enrolment), menopausal status (postmenopausal, premenopausal/unknown menopause), BMI $\left(<25, \geqslant 25 \mathrm{~kg} \mathrm{~m}^{-2}\right)$, OC use (ever, never), parity (parous, nulliparous) and self-reported endometriosis. The $P$-value for interaction was calculated using a likelihood ratio test to compare models with and without multiplicative interaction terms.

In the analyses of case subgroups classified according to tumour behaviour and histologic subtype (excluding other/undifferentiated tumours) as compared with controls, polytomous logistic regression (PLR) was used to simultaneously estimate separate risk factor associations for each subgroup and the likelihood ratio test was used to calculate a $P$-value for heterogeneity comparing a model in which all of the associations were held constant between the case subgroups to a model, which allowed only the association of interest to differ between the case subgroups (Glynn and Rosner, 2004). In all statistical analyses, a $P$-value $<0.05$ was considered as statistically significant. Analyses were performed using SAS v9.2 (SAS Institute Inc., Cary, NC, USA) and Stata v9 (StataCorp, College Station, TX, USA).

\section{RESULTS}

The study population included 1872 women with EOC and 1978 controls. The median time between the date of diagnosis with ovarian cancer and enrolment into the study was 9 months. Cases reported a shorter duration of OC use, were less likely to be parous or to report a tubal ligation and were more likely to have a family history of ovarian cancer (Table 1).

In comparisons of the highest $v s$ the lowest quartiles of intake, an increased risk for EOC overall was observed with a high intake of trans fat $(\mathrm{OR}=1.30,95 \%$ CI $1.08-1.57, \quad P$-trend $=0.002)$, whereas inverse associations were observed with increased consumption of polyunsaturated fat $(\mathrm{OR}=0.82$, 95\% CI $0.68-$ $0.99, P$-trend $=0.04)$, long chain $n-3(\mathrm{OR}=0.79,95 \%$ CI $0.66-0.96$, $P$-trend $=0.01) \quad$ and $n-6 \quad(\mathrm{OR}=0.77, \quad 95 \% \quad \mathrm{CI} \quad 0.64-0.94$, $P$-trend $=0.02$; Table 2). Associations were similar when we evaluated total intake (food plus supplement use) of long chain $n-3$ and $n-6$ (data not shown). In contrast, there was no association between intake of total fat, different sources (vegetable, animal, dairy) or other types of fat (saturated, monounsaturated, cholesterol) and risk of EOC. The primary dietary source $(41 \%)$ of $n-3$ was dark fish; an inverse association also was observed with high intake of dark fish, $\geqslant 2$ servings per week $v s$ never/less than
Table 1. Descriptive characteristics of EOC cases and controls in the New England-based case-control study

\begin{tabular}{|l|c|c|}
\hline Population characteristics & Cases & Controls \\
\hline Participants, N & 1872 & 1978 \\
\hline Means (s.d.) & $52.5(12.3)$ & $52.4(12.5)$ \\
& $5.7(5.0)$ \\
Age (years) & $4.7(4.8)$ & $26.0(5.5)$ \\
Duration of oral contraceptive use (years) $^{\text {b }}$ & $26.4(6.1)$ & $1887.5(575.4)$ \\
BMI (kg m ${ }^{-2}$ ) & $1925.1(587.7)$ & 188.1 (kcal) \\
Total calories
\end{tabular}

\section{Percentages}

\section{Parous}

Postmenopausal

History of tubal ligation

History of endometriosis ${ }^{c}$

Family history of ovarian cancer

\begin{tabular}{l|l}
67.6 & 82.4
\end{tabular}

52.8

13.6

9.3

4.8

53.0

19.7

7.8

Means (s.d.) $)^{d}$

\section{Total fat $\left(\right.$ g day $\left.^{-1}\right)$}

Vegetable fat $\left(\mathrm{g} \mathrm{day}^{-1}\right)$

Animal fat $\left(\mathrm{g} \mathrm{day}^{-1}\right)$

Trans fat $\left(\mathrm{g} \mathrm{day}^{-1}\right)$

Saturated fat $\left(\mathrm{g}_{\text {day }}{ }^{-1}\right)$

Long chain omega-3 $(n-3)^{\mathbf{e}}\left(\mathrm{g} \mathrm{day}^{-1}\right)$

Long chain omega-3 $(n-3)^{f}\left(\right.$ g day $\left.^{-1}\right)$

Omega-6 $(n-6)^{\mathbf{e}}\left(\mathrm{g} \mathrm{day}^{-1}\right)$

Omega-6 $(n-6)^{f}\left(\right.$ g day $\left.^{-1}\right)$

55.3 (10.9)

$25.2(8.1)$

30.1 (9.8)

$2.1(0.7)$

$19.3(4.8)$

$0.3(0.2)$

$0.3(0.3)$

$9.0(2.4)$

$9.0(2.4)$

2.7

Abbreviations: $\mathrm{EOC}=$ epithelial ovarian cancer; $N=$ number; $n-3=$ omega- $3 ; n-6=$ omega-6.

${ }^{a}$ Cases and controls were frequency matched on age.

${ }^{b}$ Duration of oral contraceptive use among ever users.

${ }^{c}$ Endometriosis was self-reported and not surgically confirmed.

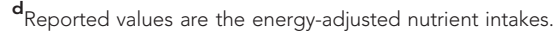

e Intakes are from foods only

$f_{\text {Intakes are from foods plus supplements. }}$

monthly, $\mathrm{OR}=0.66,95 \%$ CI $0.48-0.91$ (data not shown). In further analyses of the individual long chain $n-3$ and $n-6$ fatty acids, we observed an inverse association and significant trend of decreasing risk of EOC overall with increasing intake of the long chain $n-3$ fatty acids EPA $(P$-trend $=0.002)$, DPA $(P$-trend $=0.02)$ and DHA $(P$-trend $=0.03)$, while there was no association with alpha-linolenic acid (long chain $n-3$ ) or arachidonic acid $(n-6)$ (data not shown).

We also evaluated the associations with intake of trans fat, long chain $n-3$ and $n-6$ using the nutrient density method (i.e., the percentage of energy for each fat type); in multivariate models (including adjustment for total caloric intake) we observed similar results of an increased risk for EOC in comparisons of the highest $v s$ the lowest quartiles of intake of trans fat (quartile (Q) $4 \quad($ median $=1.7) \quad$ vs $\quad$ Q1 $\quad($ median $=0.7), \quad \mathrm{OR}=1.35,95 \% \quad \mathrm{CI}$ $1.11-1.63, P$-trend $=0.001$ ) and a decreased risk of EOC with a high intake of long chain $n-3$ (Q4 (median=0.2) vs Q1 $($ median $=0.05), \mathrm{OR}=0.78,95 \%$ CI $0.65-0.94, P$-trend $=0.02)$ and $n-6(\mathrm{Q} 4($ median $=6.8)$ vs $\mathrm{Q} 1 \quad($ median $=3.7), \mathrm{OR}=0.76$, 95\% CI 0.62-0.92, P-trend $=0.01$; data not shown).

Associations between fat intake and risk of EOC did not differ by menopausal status, BMI, OC use, parity or history of endometriosis (data not shown). However, a high total fat intake was associated with a suggestive increased risk of EOC among participants who were $<50$ years of age (Q4 vs $\mathrm{Q} 1, \mathrm{OR}=1.36$, 95\% CI $0.99-1.85$, $P$-trend $=0.07)$, whereas there was no association with total fat intake in participants who were $\geqslant 50$ 
Table 2. Association between dietary fat intake and overall EOC risk in the New England-based case-control study ${ }^{\mathrm{a}}$

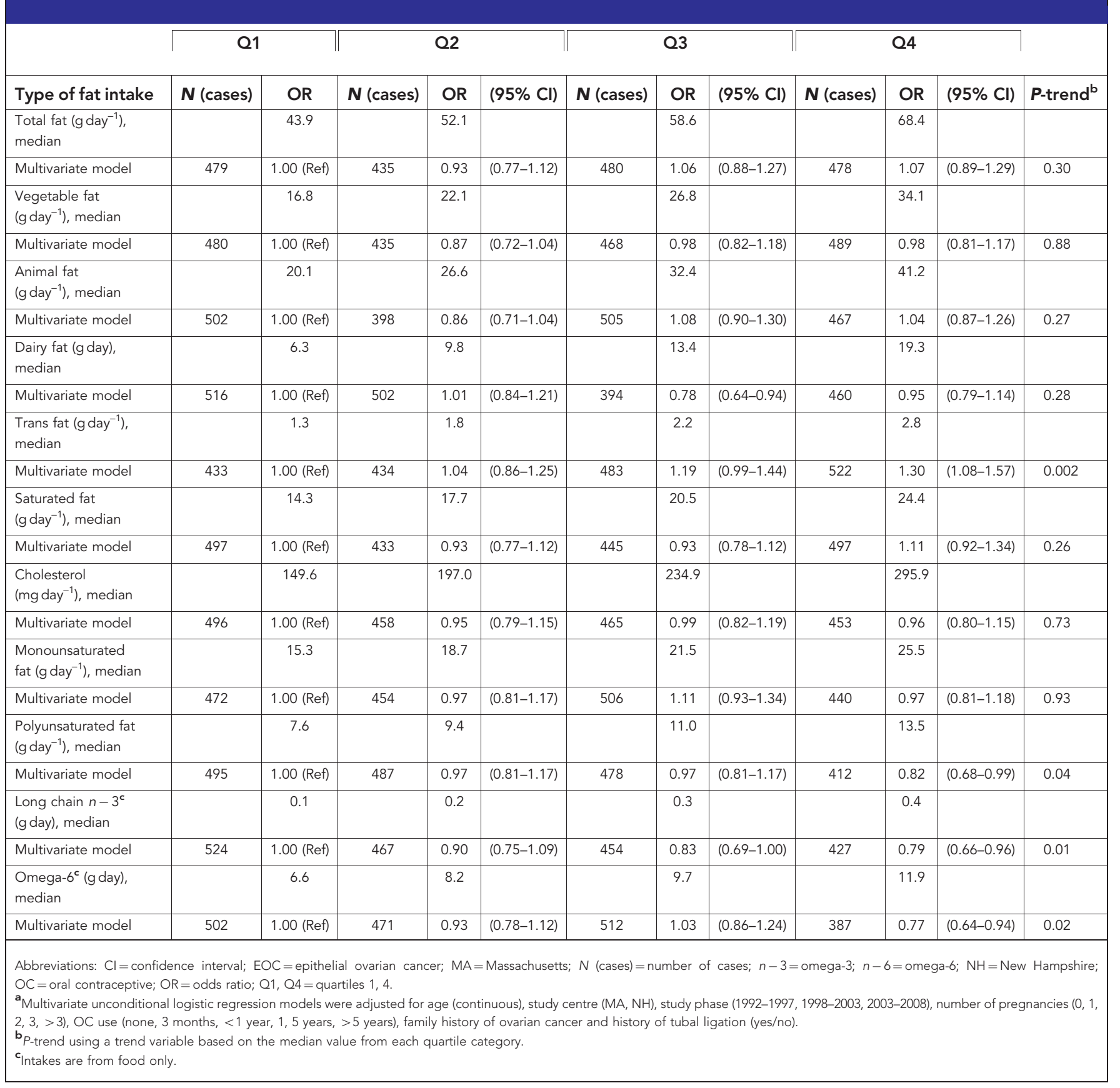

years of age $(\mathrm{OR}=0.90,95 \%$ CI $0.71-1.14, \quad P$-trend $=0.67$, $P$-interaction $=0.04)$.

Fat intake was assessed in relation to risk of EOC according to tumour behaviour and significant heterogeneity from PLR (indicating that the risk associations of interest differed across invasive and borderline tumours) was observed in analyses of vegetable fat and polyunsaturated fat (Table 3 ). In comparisons of the highest $v s$ lowest quartiles of intake, we observed inverse associations with risk of borderline tumours for vegetable fat $(\mathrm{OR}=0.71,95 \%$ CI $0.52-0.99, P$-trend $=0.09)$ and polyunsaturated fat $(\mathrm{OR}=0.56,95 \% \mathrm{CI} 0.40-0.79, \quad P$-trend $<0.001)$ as compared with no significant associations in the invasive tumours. For certain other dietary factors there were similarities in the risk associations between invasive and borderline tumours; for example, a high intake of trans fat (Q4 vs Q1) increased the risk for invasive $(\mathrm{OR}=1.28,95 \% \mathrm{CI} 1.05-1.57, P$-trend $<0.01)$ and borderline EOC $(\mathrm{OR}=1.32,95 \%$ CI $0.96-1.81, P$-trend $=0.11)$ although the latter association was nonsignificant. Intake of long chain $n-3$ showed a nonsignificant inverse association with risk of invasive EOC (Q4 vs Q1, OR $=0.85,95 \%$ CI $0.69-1.04$, $P$-trend $=0.10)$ and a significant inverse association was observed for borderline tumours (Q4 vs Q1, OR $=0.62$, 95\% CI 0.45-0.86, $P$-trend $=0.004$ ).

In analyses of fat intake in relation to risk of different histologic subtypes of EOC, none of the $P$-values for heterogeneity from PLR were statistically significant; however, a high intake of long chain $n-3$ was inversely associated with risk of endometrioid tumours (Q4 vs $\mathrm{Q} 1, \mathrm{OR}=0.58,95 \%$ CI $0.41-0.82, P$-trend $=0.003$; Table 4 ) and a similar inverse association was observed with increased consumption of dark fish (data not shown). In contrast, there was no significant association between intake of long chain $n-3$ and risk of serous, clear cell and mucinous tumours. There was, 
Table 3. Fat intake in relation to risk of invasive and borderline EOC in the New England-based case-control study ${ }^{\mathrm{a}}$

\begin{tabular}{|c|c|c|c|c|c|c|c|c|}
\hline \multirow[b]{2}{*}{ Type of fat intake } & \multirow{2}{*}{$\begin{array}{c}\text { Controls }(n=1978) \\
\text { N }\end{array}$} & \multicolumn{3}{|c|}{ Invasive $(n=1484)$} & \multicolumn{3}{|c|}{ Borderline $(n=388)$} & \multirow[b]{2}{*}{$\boldsymbol{P}$-het ${ }^{\mathrm{b}}$} \\
\hline & & $\mathbf{N}$ (cases) & OR & $(95 \% \mathrm{Cl})$ & $\mathbf{N}$ (cases) & OR & $(95 \% \mathrm{Cl})$ & \\
\hline \multicolumn{9}{|l|}{ Total fat $\left(\mathrm{g} \mathrm{day}^{-1}\right)$} \\
\hline $\begin{array}{l}\mathrm{Q} 1 \\
\mathrm{Q} 2 \\
\mathrm{Q} 3 \\
\mathrm{Q} 4 \\
\text { P-trend }\end{array}$ & $\begin{array}{l}494 \\
495 \\
495 \\
494\end{array}$ & $\begin{array}{l}384 \\
332 \\
375 \\
393\end{array}$ & $\begin{array}{l}1.00 \text { (Ref) } \\
0.87 \\
0.98 \\
1.06 \\
0.39\end{array}$ & $\begin{array}{l}(0.71-1.06) \\
(0.80-1.20) \\
(0.86-1.29)\end{array}$ & $\begin{array}{r}95 \\
103 \\
105 \\
85\end{array}$ & $\begin{array}{l}1.00 \text { (Ref) } \\
1.11 \\
1.17 \\
0.96 \\
0.89\end{array}$ & $\begin{array}{l}(0.81-1.51) \\
(0.86-1.60) \\
(0.70-1.33)\end{array}$ & 0.14 \\
\hline \multicolumn{9}{|c|}{ Vegetable fat $\left(\mathrm{g} \mathrm{day}^{-1}\right)$} \\
\hline $\begin{array}{l}\text { Q1 } \\
\text { Q2 } \\
\text { Q3 } \\
\text { Q4 } \\
\text { P-trend }\end{array}$ & $\begin{array}{l}493 \\
496 \\
495 \\
494\end{array}$ & $\begin{array}{l}376 \\
338 \\
358 \\
412\end{array}$ & $\begin{array}{l}1.00 \text { (Ref) } \\
0.85 \\
0.94 \\
1.01 \\
0.66\end{array}$ & $\begin{array}{l}(0.70-1.04) \\
(0.77-1.15) \\
(0.82-1.23)\end{array}$ & $\begin{array}{r}104 \\
97 \\
110 \\
77\end{array}$ & $\begin{array}{l}1.00 \text { (Ref) } \\
0.89 \\
1.07 \\
0.71 \\
0.09\end{array}$ & $\begin{array}{l}(0.66-1.21) \\
(0.79-1.45) \\
(0.52-0.99)\end{array}$ & 0.03 \\
\hline \multicolumn{9}{|l|}{ Animal fat $\left(\mathrm{g} \mathrm{day}^{-1}\right)$} \\
\hline $\begin{array}{l}\text { Q1 } \\
\text { Q2 } \\
\text { Q3 } \\
\text { Q4 } \\
\text { P-trend }\end{array}$ & $\begin{array}{l}495 \\
494 \\
495 \\
494\end{array}$ & $\begin{array}{l}405 \\
328 \\
385 \\
366\end{array}$ & $\begin{array}{l}1.00 \text { (Ref) } \\
0.89 \\
1.01 \\
1.01 \\
0.64\end{array}$ & $\begin{array}{l}(0.72-1.08) \\
(0.83-1.24) \\
(0.83-1.24)\end{array}$ & $\begin{array}{r}97 \\
70 \\
120 \\
101\end{array}$ & $\begin{array}{l}1.00 \text { (Ref) } \\
0.78 \\
1.34 \\
1.17 \\
0.07\end{array}$ & $\begin{array}{l}(0.56-1.10) \\
(0.99-1.80) \\
(0.86-1.60)\end{array}$ & 0.09 \\
\hline \multicolumn{9}{|l|}{ Dairy fat $\left(\mathrm{g} \mathrm{day}^{-1}\right)$} \\
\hline $\begin{array}{l}\mathrm{Q} 1 \\
\mathrm{Q} 2 \\
\mathrm{Q} 3 \\
\mathrm{Q} 4 \\
\text { P-trend }^{\mathrm{c}}\end{array}$ & $\begin{array}{l}496 \\
494 \\
495 \\
493\end{array}$ & $\begin{array}{l}419 \\
410 \\
311 \\
344\end{array}$ & $\begin{array}{l}1.00 \text { (Ref) } \\
1.06 \\
0.77 \\
0.92 \\
0.13\end{array}$ & $\begin{array}{l}(0.88-1.29) \\
(0.63-0.95) \\
(0.75-1.12)\end{array}$ & $\begin{array}{r}97 \\
92 \\
83 \\
116\end{array}$ & $\begin{array}{l}1.00 \text { (Ref) } \\
0.98 \\
0.88 \\
1.27 \\
0.11\end{array}$ & $\begin{array}{l}(0.72-1.34) \\
(0.64-1.22) \\
(0.94-1.72)\end{array}$ & 0.05 \\
\hline \multicolumn{9}{|l|}{ Trans fat $\left(\mathrm{g} \mathrm{day}^{-1}\right)$} \\
\hline $\begin{array}{l}\text { Q1 } \\
\text { Q2 } \\
\text { Q3 } \\
\text { Q4 } \\
\text { P-trend }\end{array}$ & $\begin{array}{l}491 \\
501 \\
491 \\
495\end{array}$ & $\begin{array}{l}347 \\
334 \\
385 \\
418\end{array}$ & $\begin{array}{l}1.00 \text { (Ref) } \\
0.98 \\
1.17 \\
1.28 \\
0.005\end{array}$ & $\begin{array}{l}(0.80-1.20) \\
(0.96-1.44) \\
(1.05-1.57)\end{array}$ & $\begin{array}{r}86 \\
100 \\
98 \\
104\end{array}$ & $\begin{array}{l}1.00 \text { (Ref) } \\
1.21 \\
1.23 \\
1.32 \\
0.11\end{array}$ & $\begin{array}{l}(0.88-1.66) \\
(0.89-1.69) \\
(0.96-1.81)\end{array}$ & 0.58 \\
\hline \multicolumn{9}{|c|}{ Saturated fat $\left(\mathrm{g} \mathrm{day}^{-1}\right)$} \\
\hline $\begin{array}{l}\text { Q1 } \\
\text { Q2 } \\
\text { Q3 } \\
\text { Q4 } \\
\text { P-trend }\end{array}$ & $\begin{array}{l}495 \\
494 \\
492 \\
497\end{array}$ & $\begin{array}{l}403 \\
342 \\
351 \\
388\end{array}$ & $\begin{array}{l}1.00 \text { (Ref) } \\
0.88 \\
0.86 \\
1.06 \\
0.63\end{array}$ & $\begin{array}{l}(0.72-1.08) \\
(0.70-1.05) \\
(0.87-1.29)\end{array}$ & $\begin{array}{r}94 \\
91 \\
94 \\
109\end{array}$ & $\begin{array}{l}1.00 \text { (Ref) } \\
1.03 \\
1.05 \\
1.30 \\
0.10\end{array}$ & $\begin{array}{l}(0.75-1.42) \\
(0.76-1.44) \\
(0.95-1.76)\end{array}$ & 0.55 \\
\hline \multicolumn{9}{|c|}{ Cholesterol (mg day $\left.{ }^{-1}\right)$} \\
\hline $\begin{array}{l}\text { Q1 } \\
\text { Q2 } \\
\text { Q3 } \\
\text { Q4 } \\
\text { P-trend }\end{array}$ & $\begin{array}{l}494 \\
495 \\
495 \\
494\end{array}$ & $\begin{array}{l}386 \\
357 \\
366 \\
375\end{array}$ & $\begin{array}{l}1.00 \text { (Ref) } \\
0.93 \\
1.01 \\
1.00 \\
0.82\end{array}$ & $\begin{array}{l}(0.76-1.14) \\
(0.82-1.23) \\
(0.82-1.23)\end{array}$ & $\begin{array}{r}110 \\
101 \\
99 \\
78\end{array}$ & $\begin{array}{l}1.00 \text { (Ref) } \\
0.94 \\
0.95 \\
0.75 \\
0.09\end{array}$ & $\begin{array}{l}(0.70-1.28) \\
(0.70-1.29) \\
(0.54-1.03)\end{array}$ & 0.23 \\
\hline \multicolumn{9}{|c|}{ Monounsaturated fat $\left(\mathrm{g} \mathrm{day}^{-1}\right)$} \\
\hline $\begin{array}{l}\text { Q1 } \\
\text { Q2 } \\
\text { Q3 } \\
\text { Q4 } \\
\text { P-trend }\end{array}$ & $\begin{array}{l}497 \\
493 \\
494 \\
494\end{array}$ & $\begin{array}{l}377 \\
350 \\
394 \\
363\end{array}$ & $\begin{array}{l}1.00 \text { (Ref) } \\
0.94 \\
1.00 \\
0.98 \\
0.93\end{array}$ & $\begin{array}{l}(0.77-1.15) \\
(0.82-1.22) \\
(0.80-1.19)\end{array}$ & $\begin{array}{r}95 \\
104 \\
112 \\
77\end{array}$ & $\begin{array}{l}1.00 \text { (Ref) } \\
1.11 \\
1.23 \\
0.86 \\
0.48\end{array}$ & $\begin{array}{l}(0.82-1.52) \\
(0.91-1.67) \\
(0.61-1.19)\end{array}$ & 0.16 \\
\hline \multicolumn{9}{|c|}{ Polyunsaturated fat $\left(\mathrm{g} \mathrm{day}^{-1}\right)$} \\
\hline $\begin{array}{l}\text { Q1 } \\
\text { Q2 } \\
\text { Q3 } \\
\text { Q4 } \\
\text { P-trend }\end{array}$ & $\begin{array}{l}495 \\
490 \\
499 \\
494\end{array}$ & $\begin{array}{l}384 \\
371 \\
380 \\
349\end{array}$ & $\begin{array}{l}1.00 \text { (Ref) } \\
0.95 \\
0.96 \\
0.85 \\
0.13\end{array}$ & $\begin{array}{l}(0.78-1.16) \\
(0.78-1.17) \\
(0.69-1.04)\end{array}$ & $\begin{array}{r}111 \\
116 \\
98 \\
63\end{array}$ & $\begin{array}{l}1.00 \text { (Ref) } \\
1.03 \\
0.89 \\
0.56 \\
<0.001\end{array}$ & $\begin{array}{l}(0.77-1.38) \\
(0.66-1.21) \\
(0.40-0.79)\end{array}$ & 0.03 \\
\hline
\end{tabular}




\begin{tabular}{|c|c|c|c|c|c|c|c|c|}
\hline & Controls $(n=1978)$ & \multicolumn{3}{|c|}{ Invasive $(n=1484)$} & \multicolumn{3}{|c|}{ Borderline $(n=388)$} & \multirow[b]{2}{*}{ P-het ${ }^{\text {b }}$} \\
\hline Type of fat intake & $\mathbf{N}$ & $\mathbf{N}$ (cases) & OR & $(95 \% \mathrm{Cl})$ & $\mathbf{N}$ (cases) & OR & $(95 \% \mathrm{Cl})$ & \\
\hline \multicolumn{9}{|c|}{ Long chain omega-3 $(n-3)^{d}$} \\
\hline $\begin{array}{l}\text { Q1 } \\
\text { Q2 } \\
\text { Q3 } \\
\text { Q4 } \\
\text { P-trend }\end{array}$ & $\begin{array}{l}494 \\
495 \\
495 \\
494\end{array}$ & $\begin{array}{l}405 \\
371 \\
357 \\
351\end{array}$ & $\begin{array}{l}1.00 \text { (Ref) } \\
0.93 \\
0.86 \\
0.85 \\
0.10\end{array}$ & $\begin{array}{l}(0.76-1.14) \\
(0.71-1.06) \\
(0.69-1.04)\end{array}$ & $\begin{array}{r}119 \\
96 \\
97 \\
76\end{array}$ & $\begin{array}{l}1.00 \text { (Ref) } \\
0.83 \\
0.78 \\
0.62 \\
0.004\end{array}$ & $\begin{array}{l}(0.61-1.12) \\
(0.58-1.06) \\
(0.45-0.86)\end{array}$ & 0.31 \\
\hline \multicolumn{9}{|l|}{ Omega-6 $(n-6)^{d}$} \\
\hline $\begin{array}{l}\text { Q1 } \\
\text { Q2 } \\
\text { Q3 } \\
\text { Q4 } \\
\text { P-trend } \\
\end{array}$ & $\begin{array}{l}494 \\
499 \\
491 \\
494\end{array}$ & $\begin{array}{l}376 \\
372 \\
404 \\
332\end{array}$ & $\begin{array}{l}1.00 \text { (Ref) } \\
0.97 \\
1.05 \\
0.85 \\
0.17\end{array}$ & $\begin{array}{l}(0.80-1.19) \\
(0.86-1.28) \\
(0.69-1.04)\end{array}$ & $\begin{array}{r}126 \\
99 \\
108 \\
55\end{array}$ & $\begin{array}{l}1.00 \text { (Ref) } \\
0.78 \\
0.87 \\
0.44 \\
<0.001\end{array}$ & $\begin{array}{l}(0.58-1.05) \\
(0.65-1.17) \\
(0.31-0.62)\end{array}$ & 1.00 \\
\hline \multicolumn{9}{|c|}{ 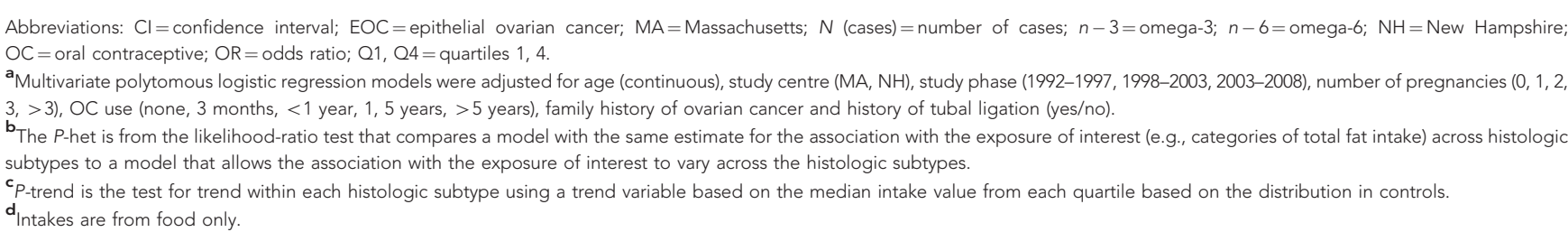 } \\
\hline
\end{tabular}

however, an inverse association with increased consumption of dark fish and risk of serous invasive tumours, $\geqslant 2$ servings per week $v s$ never/less than monthly, OR $=0.64$ (95\% CI: 0.43, 0.97), although this finding could be due to chance because only 37 cases reported a high intake of dark fish (data not shown).

\section{DISCUSSION}

In this large case-control study in New England, USA, we evaluated different types and sources of fat intake in relation to risk of EOC overall and according to tumour behaviour and histologic subtype. We observed no association between total fat intake and risk of EOC overall. Consistent with these findings, a pooled analysis of 12 cohort studies (Genkinger et al, 2006), an updated analysis of the Netherlands Cohort study (included in the pooled analysis; Gilsing et al, 2011), the California Teachers Study (Chang et al, 2007) and several case-control studies (Byers et al, 1983; Slattery et al, 1989; Salazar-Martinez et al, 2002; Pan et al, 2004) observed no association between total fat intake and EOC risk. These findings contrasted with positive associations between total fat intake and EOC risk reported in the NIH-AARP cohort (Blank et al, 2012) and an earlier meta-analysis (Huncharek and Kupelnick, 2001). It has been hypothesised that a high intake of total, saturated and/or animal fat could stimulate extraovarian oestrogen production (Hill et al, 1971), which may increase the risk for EOC (Lukanova and Kaaks, 2005). However, evidence to support the link between dietary fat intake and endogenous oestrogen levels has been inconsistent (Wu et al, 1999; Holmes et al, 2000; Cui et al, 2010).

There was no association between intake of animal or saturated fat and risk of EOC overall. These results contrasted with a positive association with animal fat intake seen in the NIH-AARP cohort (Blank et al, 2012) and a nonsignificant increased risk for EOC in the pooled analysis (including nine cohort studies) (Genkinger et al, 2006). Our finding of no association with saturated fat intake was consistent with several prospective investigations (Chang et al, 2007; Gilsing et al, 2011; Blank et al, 2012) and a case-control study (Tzonou et al, 1993). The pooled analysis observed a weak positive association with saturated fat intake in comparisons of the highest $v s$ the lowest deciles of intake but no evidence of a doseresponse (Genkinger et al, 2006).

We observed an increased risk for both invasive and borderline EOCs (nonsignificant association in borderline) with a high intake of trans fat. Gilsing et al (2011) also reported a positive association between trans fat intake and risk of invasive EOC, while the pooled analysis (Genkinger et al, 2006) observed no association. Further data are needed to evaluate the association between trans fat intake and risk of invasive and borderline EOC.

In contrast to the expected adverse effects for high consumption of the above-mentioned fats, the polyunsaturated fats, particularly the long chain $n-3$ fatty acids, may have anti-carcinogenic effects (Larsson et al, 2004). We observed an inverse association and doseresponse for risk of EOC overall with high consumption of polyunsaturated fat, long chain $n-3$ and $n-6$ fatty acids. Analyses of borderline and invasive tumours revealed that a high intake of vegetable fat and polyunsaturated fat was associated with a decreased risk for borderline tumours, whereas an increased intake of $n-3$ was inversely associated with risk of invasive EOC (nonsignificant) and borderline EOC. A nonsignificant decreased risk of EOC with high polyunsaturated fat intake also was observed in the Netherlands Cohort Study (Gilsing et al, 2011). In contrast, a weak positive association with polyunsaturated fat intake was observed in the NIH-AARP study (Blank et al, 2012) and no association was observed in the pooled analysis (including the Netherlands Cohort Study; Genkinger et al, 2006).

Regarding the inverse association with $n-6$ intake observed in this study, this finding is consistent with a decreased risk of EOC with a high $n-6$ intake in an Australian case-control study; this study further evaluated the food sources of $n-6$ and concluded that the inverse association was due to selected food sources (e.g., avocado, vegetables (not potatoes) and nuts) but not $n-6$ intake itself (Ibiebele et al, 2012). In the current study, the top two food contributors to $n-6$ were mayonnaise (11\%) and chicken without skin $(8 \%)$; hence the potential mechanisms that may explain the inverse association with $n-6$ in this study are uncertain. As most previous prospective studies have examined polyunsaturated fat 
Table 4. Fat intake in relation to risk of different histologic subtypes ${ }^{\mathbf{a}}$ of invasive EOC in the New England-based case-control study ${ }^{\mathbf{b}}$

\begin{tabular}{|c|c|c||c|}
\hline $\begin{array}{c}\text { Controls } \\
(n=1978)\end{array}$ & Serous $(n=842)$ & Endometrioid $(n=308)$ & Clear cell $(n=108)$
\end{tabular}$\quad$ Mucinous $(n=87)$

\begin{tabular}{|c|c|c|c|c|c|c|c|c|c|c|c|c|c|c|}
\hline $\begin{array}{l}\text { Type of } \\
\text { fat intake }\end{array}$ & $\mathbf{N}$ & $\begin{array}{c}\mathbf{N} \\
\text { (cases) }\end{array}$ & OR & $(95 \% \mathrm{Cl})$ & $\begin{array}{c}\mathbf{N} \\
\text { (cases) }\end{array}$ & OR & $(95 \% \mathrm{Cl})$ & $\begin{array}{c}\mathbf{N} \\
\text { (cases) }\end{array}$ & OR & $(95 \% \mathrm{Cl})$ & $\begin{array}{c}\mathbf{N} \\
\text { (cases) }\end{array}$ & OR & $(95 \% \mathrm{Cl})$ & $P$-het ${ }^{c}$ \\
\hline \multicolumn{15}{|c|}{ Total fat $\left(\mathrm{g}\right.$ day $\left.^{-1}\right)$} \\
\hline Q1 & 494 & 219 & 1.00 (Ref) & & 78 & 1.00 (Ref) & & 28 & 1.00 (Ref) & & 24 & 1.00 (Ref) & & 0.72 \\
\hline Q2 & 495 & 186 & 0.87 & $(0.68-1.10)$ & 73 & 0.96 & $(0.68-1.36)$ & 20 & 0.73 & $(0.40-1.32)$ & 17 & 0.72 & $(0.38-1.37)$ & \\
\hline Q3 & 495 & 219 & 1.03 & $(0.82-1.31)$ & 67 & 0.89 & $(0.62-1.27)$ & 29 & 1.07 & $(0.63-1.83)$ & 27 & 1.16 & $(0.66-2.05)$ & \\
\hline $\mathrm{Q} 4$ & 494 & 218 & 1.05 & $(0.83-1.33)$ & 90 & 1.22 & $(0.87-1.70)$ & 31 & 1.17 & $(0.69-1.99)$ & 19 & 0.84 & $(0.45-1.55)$ & \\
\hline$P$-trend $d^{d}$ & & & 0.42 & & & 0.26 & & & 0.35 & & & 0.88 & & \\
\hline
\end{tabular}

\section{Vegetable fat $\left(\mathrm{g} \mathrm{day}^{-1}\right)$}

\begin{tabular}{|c|c|c|c|c|c|c|c|c|c|c|c|c|c|c|}
\hline Q1 & 493 & 213 & 1.00 (Ref) & & 81 & 1.00 (Ref) & & 25 & 1.00 (Ref) & & 23 & 1.00 (Ref) & & 0.63 \\
\hline Q2 & 496 & 182 & 0.82 & $(0.64-1.04)$ & 78 & 0.92 & $(0.65-1.29)$ & 20 & 0.76 & $(0.42-1.40)$ & 25 & 1.04 & $(0.58-1.86)$ & \\
\hline Q3 & 495 & 206 & 0.98 & $(0.77-1.24)$ & 67 & 0.83 & $(0.59-1.19)$ & 30 & 1.21 & $(0.70-2.10)$ & 20 & 0.88 & $(0.47-1.62)$ & \\
\hline Q4 & 494 & 241 & 1.04 & $(0.83-1.31)$ & 82 & 0.93 & $(0.67-1.31)$ & 33 & 1.22 & $(0.71-2.08)$ & 19 & 0.76 & $(0.41-1.42)$ & \\
\hline$P$-trend ${ }^{d}$ & & & 0.39 & & & 0.66 & & & 0.25 & & & 0.32 & & \\
\hline
\end{tabular}

\section{Animal fat $\left(\mathrm{g} \mathrm{day}^{-1}\right)$}

\begin{tabular}{|c|c|c|c|c|c|c|c|c|c|c|c|c|c|c|}
\hline Q1 & 495 & 230 & 1.00 (Ref) & & 80 & 1.00 (Ref) & & 36 & 1.00 (Ref) & & 18 & 1.00 (Ref) & & 0.82 \\
\hline Q2 & 494 & 186 & 0.90 & $(0.71-1.14)$ & 69 & 0.96 & $(0.67-1.36)$ & 21 & 0.65 & $(0.37-1.13)$ & 20 & 1.23 & $(0.64-2.36)$ & \\
\hline Q3 & 495 & 217 & 1.05 & (0.84-1.33) & 84 & 1.17 & $(0.84-1.64)$ & 25 & 0.77 & $(0.46-1.31)$ & 28 & 1.74 & $(0.95-3.19)$ & \\
\hline Q4 & 494 & 209 & 1.04 & $(0.82-1.31)$ & 75 & 1.07 & $(0.76-1.51)$ & 26 & 0.82 & $(0.49-1.39)$ & 21 & 1.33 & $(0.70-2.54)$ & \\
\hline$P$-trend ${ }^{d}$ & & & 0.51 & & & 0.50 & & & 0.58 & & & 0.28 & & \\
\hline
\end{tabular}

\section{Dairy fat $\left(\mathrm{g} \mathrm{day}^{-1}\right)$}

\begin{tabular}{|c|c|c|c|c|c|c|c|c|c|c|c|c|c|c|}
\hline Q1 & 496 & 247 & 1.00 (Ref) & & 72 & 1.00 (Ref) & & 37 & 1.00 (Ref) & & 19 & 1.00 (Ref) & & 0.24 \\
\hline Q2 & 494 & 216 & 0.92 & $(0.73-1.16)$ & 100 & 1.47 & (1.05-2.04) & 24 & 0.68 & $(0.40-1.16)$ & 26 & 1.44 & (0.79-2.65) & \\
\hline Q3 & 495 & 178 & 0.77 & $(0.61-0.98)$ & 63 & 0.94 & $(0.65-1.36)$ & 22 & 0.64 & $(0.37-1.10)$ & 22 & 1.24 & $(0.66-2.34)$ & \\
\hline Q4 & 493 & 201 & 0.91 & $(0.72-1.14)$ & 73 & 1.13 & $(0.79-1.61)$ & 25 & 0.75 & $(0.44-1.27)$ & 20 & 1.17 & $(0.62-2.23)$ & \\
\hline$P$-trend ${ }^{d}$ & & & 0.30 & & & 0.89 & & & 0.31 & & & 0.83 & & \\
\hline
\end{tabular}

\section{Trans fat $\left(\mathrm{g} \mathrm{day}^{-1}\right)$}

\begin{tabular}{|c|c|c|c|c|c|c|c|c|c|c|c|c|c|c|}
\hline Q1 & 491 & 206 & 1.00 (Ref) & & 66 & 1.00 (Ref) & & 28 & 1.00 (Ref) & & 20 & 1.00 (Ref) & & 0.83 \\
\hline Q2 & 501 & 188 & 0.97 & $(0.76-1.23)$ & 78 & 1.26 & $(0.88-1.79)$ & 23 & 0.87 & $(0.49-1.54)$ & 19 & 1.01 & $(0.53-1.92)$ & \\
\hline Q3 & 491 & 199 & 1.05 & $(0.82-1.33)$ & 85 & 1.40 & $(0.98-1.98)$ & 28 & 1.08 & $(0.63-1.86)$ & 23 & 1.25 & $(0.67-2.31)$ & \\
\hline Q4 & 495 & 249 & 1.28 & $(1.02-1.62)$ & 79 & 1.27 & $(0.89-1.81)$ & 29 & 1.10 & $(0.64-1.88)$ & 25 & 1.33 & $(0.72-2.43)$ & \\
\hline$P$-trend ${ }^{d}$ & & & 0.02 & & & 0.19 & & & 0.59 & & & 0.29 & & \\
\hline
\end{tabular}

\section{Saturated fat $\left(\mathrm{g} \mathrm{day}^{-1}\right)$}

\begin{tabular}{|c|c|c|c|c|c|c|c|c|c|c|c|c|c|c|}
\hline Q1 & 495 & 229 & 1.00 (Ref) & & 76 & 1.00 (Ref) & & 36 & 1.00 (Ref) & & 24 & 1.00 (Ref) & & 0.29 \\
\hline $\mathrm{Q} 2$ & 494 & 195 & 0.92 & $(0.72-1.16)$ & 72 & 1.02 & $(0.72-1.45)$ & 23 & 0.69 & $(0.40-1.18)$ & 13 & 0.58 & $(0.29-1.16)$ & \\
\hline Q3 & 492 & 190 & 0.87 & $(0.69-1.11)$ & 74 & 1.03 & $(0.72-1.45)$ & 27 & 0.79 & $(0.47-1.33)$ & 29 & 1.27 & $(0.73-2.23)$ & \\
\hline Q4 & 497 & 228 & 1.11 & $(0.88-1.40)$ & 86 & 1.27 & $(0.90-1.78)$ & 22 & 0.68 & $(0.40-1.18)$ & 21 & 0.98 & $(0.54-1.79)$ & \\
\hline$P$-trend ${ }^{d}$ & & & 0.41 & & & 0.18 & & & 0.22 & & & 0.59 & & \\
\hline
\end{tabular}

\section{Cholesterol $\left(\mathrm{mg} \mathrm{day}^{-1}\right)$}

\begin{tabular}{|c|c|c|c|c|c|c|c|c|c|c|c|c|c|c|}
\hline Q1 & 494 & 219 & 1.00 (Ref) & & 79 & 1.00 (Ref) & & 30 & 1.00 (Ref) & & 24 & 1.00 (Ref) & & \\
\hline Q2 & 495 & 204 & 0.98 & $(0.78-1.25)$ & 68 & 0.91 & $(0.64-1.29)$ & 27 & 0.95 & $(0.56-1.63)$ & 18 & 0.79 & $(0.42-1.48)$ & 0.50 \\
\hline $\mathrm{Q} 3$ & 495 & 193 & 0.91 & $(0.72-1.16)$ & 90 & 1.18 & $(0.85-1.65)$ & 24 & 0.83 & $(0.48-1.44)$ & 27 & 1.17 & $(0.66-2.06)$ & \\
\hline Q4 & 494 & 226 & 1.06 & $(0.84-1.34)$ & 71 & 0.93 & $(0.65-1.31)$ & 27 & 0.93 & $(0.54-1.59)$ & 18 & 0.77 & $(0.41-1.45)$ & \\
\hline$P$-trend ${ }^{d}$ & & & 0.68 & & & 0.95 & & & 0.72 & & & 0.64 & & \\
\hline
\end{tabular}

\section{Monounsaturated fat $\left(\mathrm{g} \mathrm{day}^{-1}\right)$}

\begin{tabular}{|c|c|c|c|c|c|c|c|c|c|c|c|c|c|c|}
\hline Q1 & 497 & 216 & 1.00 (Ref) & & 82 & 1.00 (Ref) & & 27 & 1.00 (Ref) & & 21 & 1.00 (Ref) & & 0.92 \\
\hline Q2 & 493 & 198 & 0.92 & $(0.72-1.16)$ & 71 & 0.87 & $(0.61-1.22)$ & 22 & 0.81 & $(0.46-1.45)$ & 22 & 1.05 & $(0.57-1.94)$ & \\
\hline Q3 & 494 & 222 & 1.05 & $(0.83-1.32)$ & 74 & 0.92 & $(0.65-1.30)$ & 35 & 1.32 & $(0.78-2.22)$ & 25 & 1.21 & $(0.67-2.20)$ & \\
\hline Q4 & 494 & 206 & 0.96 & $(0.76-1.22)$ & 81 & 1.00 & $(0.71-1.40)$ & 24 & 0.90 & $(0.51-1.58)$ & 19 & 0.91 & $(0.48-1.72)$ & \\
\hline$P$-trend ${ }^{d}$ & & & 0.97 & & & 0.93 & & & 0.93 & & & 0.88 & & \\
\hline \multicolumn{15}{|c|}{ Polyunsaturated fat (g day $\left.{ }^{-1}\right)$} \\
\hline Q1 & 495 & 227 & 1.00 (Ref) & & 79 & 1.00 (Ref) & & 23 & 1.00 (Ref) & & 20 & 1.00 (Ref) & & 0.56 \\
\hline Q2 & 490 & 200 & 0.85 & $(0.68-1.08)$ & 82 & 1.01 & $(0.72-1.41)$ & 21 & 0.89 & $(0.48-1.63)$ & 26 & 1.26 & $(0.69-2.29)$ & \\
\hline Q3 & 499 & 217 & 0.93 & $(0.74-1.18)$ & 74 & 0.91 & $(0.65-1.29)$ & 32 & 1.36 & $(0.78-2.36)$ & 24 & 1.17 & $(0.64-2.15)$ & \\
\hline Q4 & 494 & 198 & 0.83 & $(0.66-1.05)$ & 73 & 0.88 & $(0.62-1.25)$ & 32 & 1.33 & $(0.76-2.31)$ & 17 & 0.81 & $(0.42-1.57)$ & \\
\hline$P$-trend ${ }^{d}$ & & & 0.20 & & & 0.40 & & & 0.17 & & & 0.45 & & \\
\hline
\end{tabular}




\begin{tabular}{|c|c|c|c|c|c|c|c|c|c|c|c|c|c|c|}
\hline \multirow[b]{2}{*}{$\begin{array}{l}\text { Type of } \\
\text { fat intake }\end{array}$} & \multirow{2}{*}{$\begin{array}{c}\begin{array}{c}\text { Controls } \\
(n=1978)\end{array} \\
\mathbf{N}\end{array}$} & \multicolumn{3}{|c|}{ Serous $(n=842)$} & \multicolumn{3}{|c|}{ Endometrioid $(n=308)$} & \multicolumn{3}{|c|}{ Clear cell $(n=108)$} & \multicolumn{3}{|c|}{ Mucinous $(n=87)$} & \multirow[b]{2}{*}{ P-het ${ }^{c}$} \\
\hline & & $\begin{array}{c}\mathbf{N} \\
\text { (cases) }\end{array}$ & OR & $(95 \% \mathrm{Cl})$ & $\begin{array}{c}\mathbf{N} \\
\text { (cases) }\end{array}$ & OR & $(95 \% \mathrm{Cl})$ & $\begin{array}{c}\mathbf{N} \\
\text { (cases) }\end{array}$ & OR & $(95 \% \mathrm{Cl})$ & $\begin{array}{c}\mathbf{N} \\
\text { (cases) }\end{array}$ & OR & $(95 \% \mathrm{Cl})$ & \\
\hline \multicolumn{15}{|c|}{ Long chain omega-3 $(\boldsymbol{n}-3)^{\mathrm{e}}\left(\mathrm{g} \mathrm{day}^{-1}\right)$} \\
\hline $\begin{array}{l}\text { Q1 } \\
\text { Q2 } \\
\text { Q3 } \\
\text { Q4 } \\
\text { P-trend }\end{array}$ & $\begin{array}{l}494 \\
495 \\
495 \\
494\end{array}$ & $\begin{array}{l}216 \\
206 \\
196 \\
224\end{array}$ & $\begin{array}{c}1.00 \text { (Ref) } \\
0.94 \\
0.86 \\
0.96 \\
0.69\end{array}$ & $\begin{array}{l}(0.75-1.19) \\
(0.67-1.09) \\
(0.76-1.21)\end{array}$ & $\begin{array}{l}96 \\
75 \\
77 \\
60\end{array}$ & $\begin{array}{c}1.00 \text { (Ref) } \\
0.77 \\
0.76 \\
0.58 \\
0.003\end{array}$ & $\begin{array}{l}(0.55-1.08) \\
(0.54-1.05) \\
(0.41-0.82)\end{array}$ & $\begin{array}{l}24 \\
32 \\
30 \\
22\end{array}$ & $\begin{array}{c}1.00 \text { (Ref) } \\
1.32 \\
1.18 \\
0.85 \\
0.39\end{array}$ & $\begin{array}{l}(0.76-2.28) \\
(0.68-2.05) \\
(0.47-1.54)\end{array}$ & $\begin{array}{l}28 \\
21 \\
19 \\
19\end{array}$ & \begin{tabular}{|c|}
1.00 (Ref) \\
0.74 \\
0.64 \\
0.63 \\
0.13
\end{tabular} & $\begin{array}{l}(0.41-1.33) \\
(0.35-1.17) \\
(0.34-1.14)\end{array}$ & 0.20 \\
\hline \multicolumn{15}{|c|}{ Omega-6 $(n-6)^{e}\left(\mathrm{~g} \mathrm{day}^{-1}\right)$} \\
\hline $\begin{array}{l}\text { Q1 } \\
\text { Q2 } \\
\text { Q3 } \\
\text { Q4 } \\
\text { P-trend d }\end{array}$ & $\begin{array}{l}494 \\
499 \\
491 \\
494\end{array}$ & $\begin{array}{l}210 \\
226 \\
208 \\
198\end{array}$ & $\begin{array}{c}1.00 \text { (Ref) } \\
1.06 \\
0.97 \\
0.90 \\
0.27 \\
\end{array}$ & $\begin{array}{l}(0.84-1.34) \\
(0.76-1.23) \\
(0.71-1.14)\end{array}$ & $\begin{array}{l}82 \\
72 \\
87 \\
67\end{array}$ & $\begin{array}{c}1.00 \text { (Ref) } \\
0.87 \\
1.04 \\
0.78 \\
0.28 \\
\end{array}$ & $\begin{array}{l}(0.61-1.22) \\
(0.74-1.44) \\
(0.55-1.11)\end{array}$ & $\begin{array}{l}25 \\
15 \\
40 \\
28\end{array}$ & $\begin{array}{c}1.00 \text { (Ref) } \\
0.59 \\
1.56 \\
1.07 \\
0.28 \\
\end{array}$ & $\begin{array}{l}(0.31-1.14) \\
(0.93-2.62) \\
(0.61-1.87)\end{array}$ & $\begin{array}{l}25 \\
21 \\
26 \\
15\end{array}$ & \begin{tabular}{|c|}
1.00 (Ref) \\
0.83 \\
1.01 \\
0.57 \\
0.15 \\
\end{tabular} & $\begin{array}{l}(0.46-1.51) \\
(0.58-1.79) \\
(0.30-1.10)\end{array}$ & 0.06 \\
\hline $\begin{array}{l}\text { Abbreviation } \\
O C=\text { oral co } \\
a_{\text {Invasive EO }} \\
b_{\text {Multivariate }} \\
3,>3 \text { ), OC } \\
{ }^{\prime} \text { The } P \text {-het is } \\
\text { subtypes to } \\
\mathbf{d}_{\text {The } P \text {-trend }} \\
\text { e }_{\text {Intakes are }}\end{array}$ & $\begin{array}{l}\mathrm{Cl}=\text { confideno } \\
\text { aceptive; } \mathrm{OR}= \\
\text { classified as o } \\
\text { lytomous logis } \\
\text { (none, } 3 \text { mont } \\
\text { om the likeliho } \\
\text { nodel, which al } \\
\text { the test for tr } \\
\mathrm{m} \text { food only. }\end{array}$ & $\begin{array}{l}\text { interval; } \\
\text { odds ratio; } \\
\text { her/undiffer } \\
\text { ic regressio } \\
\text { s, }<1 \text { year, } \\
\text { d-ratio test } \\
\text { ows the ass } \\
\text { d within e }\end{array}$ & $\begin{array}{l}O C=\text { epith } \\
P \text {-het }=P \text {-va } \\
\text { entiated we } \\
\text { n models we } \\
1,5 \text { years, } \\
\text { that compar } \\
\text { ociation with } \\
\text { ach histolog }\end{array}$ & $\begin{array}{l}\text { lial ovarian } \\
\text { lue for hetero } \\
\text { re excluded fr } \\
\text { re adjusted fo } \\
\text { es years), fam } \\
\text { es a model wi } \\
\text { the exposure } \\
\text { c subtype usi }\end{array}$ & $\begin{array}{l}\text { geneity; } \mathrm{Q} \\
\text { om this an } \\
\text { hily history } \\
\text { th the same } \\
2 \text { of interes } \\
\text { ng a trend }\end{array}$ & $\begin{array}{l}\text {, Massachu } \\
\text { Q4ysis. } \\
\text { inuous), stuo } \\
\text { f ovarian ce } \\
\text { estimate fo } \\
\text { to vary acr } \\
\text { variable bas }\end{array}$ & $\begin{array}{l}\text { setts; } N \text { (case } \\
\text { iles } 1,4 \text {. } \\
\text { y centre (MA, } \\
\text { ncer and hist } \\
\text { the associati } \\
\text { ss the histolo } \\
\text { d on the med }\end{array}$ & $\begin{array}{l}\mathrm{NH} \text { ), study } \\
\text { ory of tubal } \\
\text { on with the } \\
\text { gic subtyp } \\
\text { dian intake }\end{array}$ & $\begin{array}{l}\text { of cases; } \\
\text { phase (1992- } \\
\text { l ligation (ye } \\
\text { exposure of } \\
\text { es. } \\
\text { value from }\end{array}$ & $\begin{array}{l}\text { 1997, 1998-20 } \\
\text { s/no). } \\
\text { interest (e.g., } \\
\text { each quartile }\end{array}$ & $\begin{array}{l}03,2003-2 \\
\text { categories } \\
\text { sased on th }\end{array}$ & $\begin{array}{l}=\text { omega-6; } \\
\text { of), number } \\
\text { of total fat ir } \\
\text { he distributio }\end{array}$ & $\begin{array}{l}\text { of pregnancie } \\
\text { take) across h } \\
\text { in in controls. }\end{array}$ & $\begin{array}{l}\text { es }(0,1,2 \text {, } \\
\text { iistologic }\end{array}$ \\
\hline
\end{tabular}

intake overall but not $n-6$ specifically, further work is needed to evaluate the association between intake of $n-6$ and EOC risk.

There was no significant heterogeneity in the associations with total fat intake, fat types or sources across different histologic subtypes of EOC in this study. In an Italian case-control study, there also were no notable differences in the risk associations with intake of monounsaturated or polyunsaturated fat across histologic subtypes of EOC (Chiaffarino et al, 2007). However, we noted a strong inverse association and a dose-response between intake of long chain $n-3$ and risk of endometrioid EOC. A similar inverse association also was observed in analyses of the primary dietary source of $n-3$ (dark fish). In contrast, there was no association between intake of long chain $n-3$ with risk of serous, clear cell and mucinous EOC. The inverse association between long chain $n-3$ intake and risk of endometrioid EOC parallels a recent finding that women with the highest intake of long chain $n-3$ were less likely to develop endometriosis (Missmer et al, 2010). Both epidemiological evidence (Somigliana et al, 2006; Pearce et al, 2012; Merritt et al, 2013) and reports of shared mutations in ARID1A between endometrioid/clear cell EOC and contiguous atypical endometriosis (Wiegand et al, 2010; Yamamoto et al, 2012) suggest that specific subtypes of endometriomas may be a putative precursor lesion for endometrioid and clear cell EOC. However, we observed no association between intake of long chain $n-3$ and risk of clear cell EOC, nor confounding or effect modification by self-reported history of endometriosis, which suggested that $n-3$ intake may not be relevant to all endometriosis-related ovarian tumours and/or among all women with endometriosis.

Study limitations include the potential for exposure measurement error as diet was assessed using a FFQ and was based on a single time point. It is also possible that there could be differential diet recall in cases and controls and/or cases could have changed their diet because of symptoms of preclinical disease, since the time period of dietary assessment referred to intake that occurred 1 year before diagnosis. However, many of the associations that were observed in this study were consistent with findings from prospective analyses, which suggest that the influence of recall bias and/or changes in diet because of preclinical disease did not have a major influence on the results. A strong inverse association between long chain $n-3$ fat intake and endometrioid EOC risk but not other histologic subtypes lends support to a lack of differential recall because cases with different tumour subtypes are unlikely to recall their fat intake differently. Another limitation is that because the cases in this study were recruited after their diagnosis, the most aggressive cases could be missed. However, we previously observed no difference in the distribution by histologic subtype for the enrolled and unenrolled cases (including the most aggressive serous invasive tumours) and the histologic subtype distribution in this study was similar to that reported in the SEER data (Howlader et al, 2012; Merritt et al, 2013). Furthermore, although there is currently very little known about the dietary factors that could influence survival following a diagnosis of EOC (Bandera et al, 2009), an Australian case-control study reported no association between different types of fat intake and EOC survival (Nagle et al, 2003), which suggests that survival bias did not greatly influence the current results. Selection bias among the controls could also influence the study findings because the response rate among controls was lower (54\%) in the latter two study phases. In analyses of tumour behaviour and histologic subtype, classification was improved by having the study pathologist abstract data from all of the pathology reports; however, without a formal review of the specimen slides it is possible that there may be some misclassification. Finally, as risk factor associations were evaluated in several case subgroups this required multiple statistical tests and therefore some of the significant findings may be due to chance.

A major strength of this study was that we evaluated the associations between different types and sources of fat in a large number of cases and population-based controls (1872 and 1978, respectively) that provided an opportunity to investigate the less common histologic subtypes of EOC. We also have collected detailed information on diet as well as information about known and suspected risk factors for EOC using in-person interviews that could be accounted for in these analyses. 
In summary, in this study of the associations between intake of different sources and types of dietary fat intake and risk of EOC overall and according to tumour behaviour and histologic subtype, key findings included observation of a significantly decreased risk of EOC overall with a high intake of long chain $n-3$ and $n-6$ fatty acids, and an increased risk of EOC with high consumption of trans fat. The inverse association with high intake of long chain $n-3$ was most consistent for endometrioid EOC, which complemented a recent report of an inverse association between the consumption of long chain $n-3$ and risk of endometriosis, a putative precursor lesion for endometrioid EOC. We also observed inverse associations with $n-6$ for EOC overall and for borderline tumours. Importantly, these studies highlighted dietary factors (long chain $n-3, n-6$ ) that may enhance understanding of the aetiology of EOC and with further validation could lead to the development of strategies for the prevention of EOC.

\section{ACKNOWLEDGEMENTS}

This work was supported by the National Cancer Institute at the National Institutes of Health grants R01CA54419 and P50CA105009; the Department of Defense grant W81XWH-101-0280 to Kathryn L Terry. Melissa A Merritt was supported by a training grant NIH R25CA098566. The authors thank Mary De Pari and Cameron Fraer for their assistance in all aspects of this study. They are also grateful to the participants of the NECC study for their valuable contribution to this research.

\section{REFERENCES}

Armstrong B, Doll R (1975) Environmental factors and cancer incidence and mortality in different countries, with special reference to dietary practices. Int J Cancer 15(4): 617-631.

Bandera EV, Kushi LH, Rodriguez-Rodriguez L (2009) Nutritional factors in ovarian cancer survival. Nutr Cancer 61(5): 580-586.

Blank MM, Wentzensen N, Murphy MA, Hollenbeck A, Park Y (2012) Dietary fat intake and risk of ovarian cancer in the NIH-AARP Diet and Health Study. Br J Cancer 106(3): 596-602.

Byers T, Marshall J, Graham S, Mettlin C, Swanson M (1983) A case-control study of dietary and nondietary factors in ovarian cancer. J Natl Cancer Inst 71(4): 681-686.

Chang ET, Lee VS, Canchola AJ, Clarke CA, Purdie DM, Reynolds P, Anton-Culver H, Bernstein L, Deapen D, Peel D, Pinder R, Ross RK, Stram DO, West DW, Wright W, Ziogas A, Horn-Ross PL (2007) Diet and risk of ovarian cancer in the California Teachers Study cohort. Am J Epidemiol 165(7): 802-813.

Chiaffarino F, Parazzini F, Bosetti C, Franceschi S, Talamini R, Canzonieri V, Montella M, Ramazzotti V, La Vecchia C (2007) Risk factors for ovarian cancer histotypes. Eur J Cancer 43(7): 1208-1213.

Cui X, Rosner B, Willett WC, Hankinson SE (2010) Dietary fat, fiber, and carbohydrate intake and endogenous hormone levels in premenopausal women. Horm Cancer 1(5): 265-276.

Ferlay J, Shin HR, Bray F, Forman D, Mathers C, Parkin DM (2010) Estimates of worldwide burden of cancer in 2008: GLOBOCAN 2008. Int J Cancer 127(12): 2893-2917.

Garland M, Sacks FM, Colditz GA, Rimm EB, Sampson LA, Willett WC, Hunter DJ (1998) The relation between dietary intake and adipose tissue composition of selected fatty acids in US women. Am J Clin Nutr 67(1): $25-30$.

Genkinger JM, Hunter DJ, Spiegelman D, Anderson KE, Beeson WL, Buring JE, Colditz GA, Fraser GE, Freudenheim JL, Goldbohm RA, Hankinson SE, Koenig KL, Larsson SC, Leitzmann M, McCullough ML, Miller AB, Rodriguez C, Rohan TE, Ross JA, Schatzkin A, Schouten LJ, Smit E, Willett WC, Wolk A, Zeleniuch-Jacquotte A, Zhang SM, Smith-Warner SA (2006) A pooled analysis of 12 cohort studies of dietary fat, cholesterol and egg intake and ovarian cancer. Cancer Causes Control 17(3): 273-285.

Gilsing AM, Weijenberg MP, Goldbohm RA, van den Brandt PA, Schouten LJ (2011) Consumption of dietary fat and meat and risk of ovarian cancer in the Netherlands Cohort Study. Am J Clin Nutr 93(1): 118-126.

Glynn RJ, Rosner B (2004) Methods to evaluate risks for composite end points and their individual components. J Clin Epidemiol 57(2): 113-122.

Greenland S (1989) Modeling and variable selection in epidemiologic analysis. Am J Public Health 79(3): 340-349.

Harris HR, Cramer DW, Vitonis AF, Depari M, Terry KL (2011) Folate, vitamin $\mathrm{B}(6)$, vitamin $\mathrm{B}(12)$, methionine and alcohol intake in relation to ovarian cancer risk. Int J Cancer 131(4): E518-E529.

Hill MJ, Goddard P, Williams RE (1971) Gut bacteria and aetiology of cancer of the breast. Lancet 2(7722): 472-473.

Holmes MD, Spiegelman D, Willett WC, Manson JE, Hunter DJ, Barbieri RL, Colditz GA, Hankinson SE (2000) Dietary fat intake and endogenous sex steroid hormone levels in postmenopausal women. J Clin Oncol 18(21): 3668-3676.

Howlader N, Noone A, Krapcho M, Neyman N, Aminou R, Altekruse S, Kosary C, Ruhl J, Tatalovich Z, Cho H, Mariotto A, Eisner M, Lewis D, Chen H, Feuer E, Cronin K (2012) SEER Cancer Statistics Review, 1975-2009 (Vintage 2009 Populations). National Cancer Institute: Bethesda, MD, USA.

Huncharek M, Kupelnick B (2001) Dietary fat intake and risk of epithelial ovarian cancer: a meta-analysis of 6,689 subjects from 8 observational studies. Nutr Cancer 40(2): 87-91.

Ibiebele TI, Nagle CM, Bain CJ, Webb PM (2012) Intake of omega-3 and omega- 6 fatty acids and risk of ovarian cancer. Cancer Causes Control 23(11): 1775-1783.

Larsson SC, Kumlin M, Ingelman-Sundberg M, Wolk A (2004) Dietary long-chain $n-3$ fatty acids for the prevention of cancer: a review of potential mechanisms. Am J Clin Nutr 79(6): 935-945.

Lukanova A, Kaaks R (2005) Endogenous hormones and ovarian cancer: epidemiology and current hypotheses. Cancer Epidemiol Biomarkers Prev 14(1): 98-107.

Merritt MA, De Pari M, Vitonis AF, Titus LJ, Cramer DW, Terry KL (2013) Reproductive characteristics in relation to ovarian cancer risk by histologic pathways. Hum Reprod 28(5): 1406-1417.

Missmer SA, Chavarro JE, Malspeis S, Bertone-Johnson ER, Hornstein MD, Spiegelman D, Barbieri RL, Willett WC, Hankinson SE (2010) A prospective study of dietary fat consumption and endometriosis risk. Hum Reprod 25(6): 1528-1535.

Nagle CM, Purdie DM, Webb PM, Green A, Harvey PW, Bain CJ (2003) Dietary influences on survival after ovarian cancer. Int J Cancer 106(2): 264-269.

Pan SY, Ugnat AM, Mao Y, Wen SW, Johnson KC (2004) A case-control study of diet and the risk of ovarian cancer. Cancer Epidemiol Biomarkers Prev 13(9): 1521-1527.

Pearce CL, Templeman C, Rossing MA, Lee A, Near AM, Webb PM, Nagle CM, Doherty JA, Cushing-Haugen KL, Wicklund KG, Chang-Claude J, Hein R, Lurie G, Wilkens LR, Carney ME, Goodman MT, Moysich K, Kjaer SK, Hogdall E, Jensen A, Goode EL, Fridley BL, Larson MC, Schildkraut JM, Palmieri RT, Cramer DW, Terry KL, Vitonis AF, Titus LJ, Ziogas A, Brewster W, Anton-Culver H, Gentry-Maharaj A, Ramus SJ, Anderson AR, Brueggmann D, Fasching PA, Gayther SA, Huntsman DG, Menon U, Ness RB, Pike MC, Risch H, Wu AH, Berchuck A (2012) Association between endometriosis and risk of histological subtypes of ovarian cancer: a pooled analysis of case-control studies. Lancet Oncol 13(4): 385-394.

Prentice RL, Sheppard L (1990) Dietary fat and cancer: consistency of the epidemiologic data, and disease prevention that may follow from a practical reduction in fat consumption. Cancer Causes Control 1(1): 81-97.

Prentice RL, Thomson CA, Caan B, Hubbell FA, Anderson GL, Beresford SA, Pettinger M, Lane DS, Lessin L, Yasmeen S, Singh B, Khandekar J, Shikany JM, Satterfield S, Chlebowski RT (2007) Low-fat dietary pattern and cancer incidence in the Women's Health Initiative Dietary Modification Randomized Controlled Trial. J Natl Cancer Inst 99(20): 1534-1543.

Rimm EB, Giovannucci EL, Stampfer MJ, Colditz GA, Litin LB, Willett WC (1992) Reproducibility and validity of an expanded self-administered semiquantitative food frequency questionnaire among male health professionals. Am J Epidemiol 135(10): 1114-1126, discussion 1127-1136. 
Salazar-Martinez E, Lazcano-Ponce EC, Gonzalez Lira-Lira G, Escudero-De los Rios P, Hernandez-Avila M (2002) Nutritional determinants of epithelial ovarian cancer risk: a case-control study in Mexico. Oncology 63(2): 151-157.

Slattery ML, Schuman KL, West DW, French TK, Robison LM (1989) Nutrient intake and ovarian cancer. Am J Epidemiol 130(3): 497-502.

Somigliana E, Vigano P, Parazzini F, Stoppelli S, Giambattista E, Vercellini P (2006) Association between endometriosis and cancer: a comprehensive review and a critical analysis of clinical and epidemiological evidence. Gynecol Oncol 101(2): 331-341.

Terry KL, De Vivo I, Titus-Ernstoff L, Sluss PM, Cramer DW (2005) Genetic variation in the progesterone receptor gene and ovarian cancer risk. Am J Epidemiol 161(5): 442-451.

Tzonou A, Hsieh CC, Polychronopoulou A, Kaprinis G, Toupadaki N, Trichopoulou A, Karakatsani A, Trichopoulos D (1993) Diet and ovarian cancer: a case-control study in Greece. Int J Cancer 55(3): 411-414.

U.S. Department of Agriculture Agricultural Research Service (2011) USDA National Nutrient Database for Standard Reference: Nutrient Data Laboratory Home Page.

Wiegand KC, Shah SP, Al-Agha OM, Zhao Y, Tse K, Zeng T, Senz J, McConechy MK, Anglesio MS, Kalloger SE, Yang W, Heravi-Moussavi A, Giuliany R, Chow C, Fee J, Zayed A, Prentice L, Melnyk N, Turashvili G, Delaney AD, Madore J, Yip S, McPherson AW, Ha G, Bell L, Fereday S, Tam A, Galletta L, Tonin PN, Provencher D, Miller D, Jones SJ, Moore RA, Morin GB, Oloumi A, Boyd N, Aparicio SA, Shih Ie M,
Mes-Masson AM, Bowtell DD, Hirst M, Gilks B, Marra MA, Huntsman DG (2010) ARID1A mutations in endometriosis-associated ovarian carcinomas. N Engl J Med 363(16): 1532-1543.

Willett W, Stampfer M (1998) Implications of total energy intake for epidemiologic analyses. In Nutritional epidemiology, 2nd edn, pp 273-301. Oxford University Press: Oxford.

Willett W, Stampfer MJ (1986) Total energy intake: implications for epidemiologic analyses. Am J Epidemiol 124(1): 17-27.

Willett WC, Sampson L, Stampfer MJ, Rosner B, Bain C, Witschi J, Hennekens CH, Speizer FE (1985) Reproducibility and validity of a semiquantitative food frequency questionnaire. Am J Epidemiol 122(1): 51-65.

Wu AH, Pike MC, Stram DO (1999) Meta-analysis: dietary fat intake, serum estrogen levels, and the risk of breast cancer. J Natl Cancer Inst 91(6): 529-534.

Yamamoto S, Tsuda H, Takano M, Tamai S, Matsubara O (2012) Loss of ARID1A protein expression occurs as an early event in ovarian clear-cell carcinoma development and frequently coexists with PIK3CA mutations. Mod Pathol 25(4): 615-624.

This work is published under the standard license to publish agreement. After 12 months the work will become freely available and the license terms will switch to a Creative Commons AttributionNonCommercial-Share Alike 3.0 Unported License. 